\title{
JOURNAL.RU
}

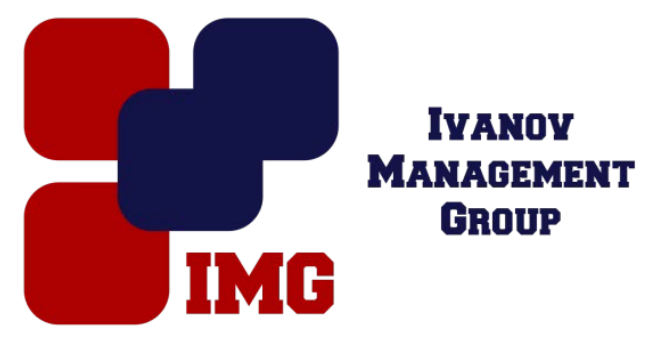

\author{
Акбашева Д. М., Кушхова Л.М. \\ Северо-Кавказская Государственная Гуманитарно-Технологическая Академия \\ Черкесск, Россия
}

doi: 10.18411/lj-25-12-2016-3-03

idsp 000001:lj-25-12-2016-3-03

\section{Особенности сельскохозяйственного производства}

\section{Аннотация}

Сельское хозяйство - самая обширная жизненно важная отрасль народного хозяйства, определяющая уровень жизни людей.

Характерной чертой сельскохозяйственного воспроизводства представляется сезонный характер производственных действий. Данное обуславливает отличный от многих индустриальных сфер порядок формирования используемого капитала и воспроизводства рабочей силы. Так как технологический процесс производства и реализации сельскохозяйственной продукции занимает несколько месяцев, то обеспечить норматив оборотных средств за счет собственных источников не только не допустимо, но и экономически не обоснованно - избыток оборотных средств, образуемый в межсезонье, омертвляет капитал и создает предпосылки для не целевого либо неэффективного применения временно свободных средств.

Ключевые слова: сельскохозяйственное производство, аграрная продукция.

Сельскохозяйственное производство связано с биологическими и естественными процессами, находится в прямой зависимости от климатических факторов, вовлеченности в производство человека, земли, растений, животных, разнородного по своему составу и назначению основного и оборотного капитала и является очень трудной формой хозяйственной деятельности. Эти особенности более ценно проявляются в условиях рыночной экономики при свободной конкурентной борьбы и недостающем регулировании государством происходящих процессов. Назовем наиболее характерные особенности сельского хозяйства:

1. В качестве основного, незаменимого средства производства в сельском хозяйстве выступает земля. Высококачественное состояние земли улучшается рядом c еe рациональном хозяйственном 
использовании равно как средства производства. Тем не менее с целью укрепления необходимого уровня плодородия необходимо возмещать не только лишь использованные питательные элементы почвы, но и восстанавливать высококачественные характеристики, что связано со значительными материально-техническими и экономическими инвестициями.

2. В ходе производства сельскохозяйственной продукции деятельность человека наиболее тесным способом переплетена с неподвластными ему природными условиями, в связи с этим возможность окупаемости денежных средств и извлечения доходы связаны с огромным риском. В то же время в сельском хозяйстве совершается наиболее стремительный износ производственных фондов аграрного назначения ввиду их деятельность в неблагоприятных условиях, в том числе в агрессивных средах (в животноводстве, птицеводстве, при работе с минеральными удобрениями.

3. Значительное отличие сельскохозяйственного производства от многих секторов экономики состоит в том, что оно не столь продуктивно по сравнению с ними. Инвестированный в него основной капитал приносит меньший доход. В следствии этого низкодоходное аграрное хозяйство не в состоянии на равных (согласно сопоставлению с индустрией) принимать участие в межотраслевой конкурентной борьбы без внешней помощи.

4. Научно-техническое развитие в аграрном хозяйстве внедряется и выражается медленнее, нежели чем в промышленности.

5. Сельское хозяйство отличается консервативностью и неэластичностью, неадекватностью реагирования на обстоятельства и условия рынка. Таким образом, при увеличении спроса на сельхозпродукцию характерные черты сельскохозяйственного производства никак не предоставляют возможности стремительно среагировать и повысить производство продукта. Существует ряд ограничений по увеличению темпов роста сельхозпроизводства. Невозможно значительно увеличить участок возделываемых земель, даже при обстоятельстве увеличения вложений. Это связано с непосредственной ограниченностью аграрных угодий. Увеличение поголовья скота, особого маточного, связан с достаточно длительным для многочисленных разновидностей животных временным периодом его выращивания. Таким образом, для того чтобы вырастить дойное стадо с целью изготовления молока необходимо примерно 3 года. Для того чтобы создать плодоносящий сад, необходимо наиболее 5 лет, виноградники - никак не меньше 3 лет и т. д. 
6. При падении спроса на пищевые продукты сельское хозяйство в силу собственной инертности и консервативности никак не имеет возможность быстро адаптироваться к меняющейся ситуации.

7. В условиях неконтролируемой рыночной экономики, при свободной конкурентной борьбы цены в монополизированном секторе индустрии увеличиваются существенно быстрее, нежели в демонополизированном сельскохозяйственном секторе, что формирует непреодолимое для аграрного производства неравенство цен, между стоимостью аграрной продукции и стоимостью ресурсов, требуемых для изготовления указанного продукта.

Следует отметить, что эти ярко выраженные особенности сельского хозяйства существенно снижают его привлекательность для инвесторов. Указанные особенности сельского хозяйства порождают необходимость постоянного вмешательства и поддержки государства.

\section{Литература}

1. http://revolution.allbest.ru/agriculture/00000426_0.html

2. http://refeteka.ru/r-117505.html

3. Бородин, В.А. Бухгалтерский учет [Электронный ресурс]: учебник/ Бородин В.А.- Электрон. текстовые данные.- М.: ЮНИТИ-ДАНА, 2012.- 528 с.

4. Широбоков, В.Г. Бухгалтерский учет в организациях АПК: Учебник / В.Г. Широбоков. - М.: ФиС, 2013. - 688 с. 